\title{
Estimation of recharge in mountain hard-rock aquifers based on discrete spring discharge monitoring during base-flow recession
}

\author{
Stefano Segadelli ${ }^{1} \cdot$ Maria Filippini $^{2} \cdot$ Anna Monti $^{2} \cdot$ Fulvio Celico $^{3} \cdot$ Alessandro Gargini $^{2}$
}

Received: 10 July 2020 / Accepted: 30 January 2021 / Published online: 17 March 2021

(C) The Author(s) 2021

\begin{abstract}
Estimation of aquifer recharge is key to effective groundwater management and protection. In mountain hard-rock aquifers, the average annual discharge of a spring generally reflects the vertical aquifer recharge over the spring catchment. However, the determination of average annual spring discharge requires expensive and challenging field monitoring. A power-law correlation was previously reported in the literature that would allow quantification of the average annual spring discharge starting from only a few discharge measurements in the low-flow season, in a dry summer climate. The correlation is based upon the Maillet model and was previously derived by a 10-year monitoring program of discharge from springs and streams in hard-rock aquifers composed of siliciclastic and calcareous turbidites that did not have well defined hydrogeologic boundaries. In this research, the same correlation was applied to two ophiolitic (peridotitic) hard-rock aquifers in the Northern Apennines (Northern Italy) with well-defined hydrogeologic boundaries and base-outflow springs. The correlation provided a reliable estimate of the average annual spring discharge thus confirming its effectiveness regardless of bedrock lithology. In the two aquifers studied, the measurable annual outputs (i.e. sum of average annual spring discharges) could be assumed equal to the annual inputs (i.e. vertical recharge) based on the clear-cut aquifer boundaries and a quick groundwater circulation inferable from spring water parameters. Thus, in such setting, the aforementioned correlation also provided an estimate of the annual aquifer recharge allowing the assessment of coefficients of infiltration (i.e. ratio between aquifer recharge and total precipitation) ranging between 10 and $20 \%$.
\end{abstract}

Keywords Fractured rocks $\cdot$ Italy $\cdot$ Groundwater recharge $\cdot$ Base-flow recession $\cdot$ Power-law correlation

\section{Introduction}

Hard rocks cover approximately the $20-35 \%$ of the Earth surface and many are utilized as important aquifers (Amiotte Suchet et al. 2003; Gustafson and Krásný 1994). Several of these aquifers are in mountainous areas, playing a major role in water supply along with the aquifers in flat areas of the

Maria Filippini

maria.filippini3@unibo.it

1 Geological, Seismic and Soil Service, Emilia-Romagna Region Administration, Viale della Fiera 8, 4027 Bologna, Italy

2 Department of Biological, Geological, and Environmental Sciences, Alma Mater Studiorum - University of Bologna, via Zamboni 67, 40126 Bologna, Italy

3 Department of Chemistry, Life Sciences and Environmental Sustainability, University of Parma, Parco Area delle Scienze 157/A, 43124 Parma, Italy planet (Hilberg 2016; Viviroli et al. 2007). The quantification of recharge in hard rock mountain aquifers is a key issue for the management of valuable groundwater resources as well as for the assessment of climate change impacts. Several reviews have been published that describe the main approaches for aquifer recharge estimation such as water balance methods, tracer methods, numerical methods, water-table fluctuation, river hydrograph separation, etc. (e.g. Cuthbert 2010; de Vries and Simmers 2002; Healy 2010; Huet et al. 2016; Scanlon et al. 2002). However, many of these approaches require a large amount of information from long and complex field monitoring campaigns that are hardly feasible in mountain catchments. Moreover, the hard rock environment provides additional challenges for recharge estimate due to the highly heterogeneous nature of the geologic materials (e.g. Rohde et al. 2015a; Rohde et al. 2015b; Thivya et al. 2016). For such challenging types of aquifers, more manageable approaches would be needed requiring only a few field measurements to optimize the aquifer recharge assessment. 
Gargini et al. (2008) investigated the groundwater flow systems within sedimentary hard rock aquifers in the Northern Apennines (Italy), composed of calcareous and siliciclastic turbidites. It is worth noting that the term 'hard rock aquifer' is generally related to igneous and metamorphic rocks (Dewandel et al. 2006, 2011; Lachassagne 2008; Lachassagne et al. 2011; Neuman 2005); however, in some circumstances, sedimentary rocks exhibit heterogeneous and anisotropic hydraulic conductivity distributions similar to those commonly observed for hard rock units, as in the case of the calcareous and siliciclastic turbidite formations in the Northern Apennines (Gargini et al. 2014; Piccinini et al. 2013). Such units behave as very transmissive aquifers in favorable structural conditions, as evidenced by Gargini et al. (2006), Vincenzi et al. (2009), and Vincenzi et al. (2014) while investigating the hydrogeological effects induced by the drilling of a high-speed railway tunnel connecting Bologna and Florence (Italy). Gargini et al. (2008), based on a large database of flow rate measurements in springs and streams collected throughout more than 10 years, found an empirical power-law correlation between the average discharge of a spring during base-flow recession and its average annual discharge, in a dry summer climate. The correlation is controlled by the base-flow recession coefficient according to the exponential Maillet model (Maillet 1905). Assuming that the annual average discharge of a spring equals the water flow that enters the aquifer over the spring catchment, the correlation would allow estimating the annual recharge of the aquifer starting from a few measurements of spring flow rates during the base-flow recession. However, since the investigated turbiditic aquifers do not have well-defined hydrogeologic boundaries and catchments, the proposed relationship could not be exploited for the estimation of aquifer recharge.

This report aims to validate the aforementioned correlation in a new setting that also has convenient boundary conditions for the estimation of aquifer recharge. To these aims, the study identified two hard-rock aquifers with a well-defined catchment where the whole measurable discharge (i.e. the sum of spring discharges), with no loss, could be assumed equal to the recharge of the system. The two aquifers are ophiolitic olistolites (known as Mt. Prinzera and Mt. Zirone), mainly composed of fractured peridotites and fully surrounded by low-permeability units behaving as aquitards. These are located in the western sector of the Northern Apennines, in a climatic and structural setting analogous to that investigated by Gargini et al. (2008). The two selected aquifers are of environmental and social interest being located in a natural reserve area (Mt. Prinzera) and being exploited for public water supply (Mt. Zirone).

\section{Materials and methods}

\section{Geological and hydrogeological setting}

The two study areas of Mt. Prinzera and Mt. Zirone are located near the confluence between the Taro and Ceno streams, about $36 \mathrm{~km} \mathrm{SW}$ of the town of Parma, in the western sector of the Northern Apennines (Emilia-Romagna Region, Italy; Fig. 1). The Northern Apennines are a typical thrust-fold chain originated from the convergence and collision between the Eurasian and African plates after the consumption of the paleo-Tethys oceanic crust of the Ligurian-Piedmont basin. Some ophiolitic bodies outcrop along the chain as isolated remnants of obducted oceanic crust. These are mostly peridotites, serpentinites, gabbros and basalts formed in the Middle to Upper Jurassic (Marroni et al. 2010) that today are embodied within allochthonous Ligurian silty-clayey complexes (Abbate 1986; Bortolotti et al. 2001).

Mt. Prinzera and Mt. Zirone are ophiolitic mountainous reliefs (olistolithes) mainly consisting of strongly serpentinized peridotites (Di Dio et al. 2005; Venturelli et al. 1997) outcropping along an orographic culmination of the external portion of the liguride units. The Mt. Prinzera ophiolitic structure covers an area of about $0.9 \mathrm{~km}^{2}$ reaching a peak elevation of $725 \mathrm{~m}$ above sea level (asl); it is about $250 \mathrm{~m}$ thick and gently dips to the north. The Mt. Zirone ophiolite covers an area of about $2.6 \mathrm{~km}^{2}$ with a maximum elevation of $707 \mathrm{~m}$ asl; it is $50 \mathrm{~m}$ thick and dips to the northwest. The ophiolitic rock masses have a very low matrix permeability but appear extensively fractured thus behaving as aquifers. Hydraulic tests provided a hydraulic conductivity ranging between $1.1 \times 10^{-7}$ and $5.7 \times 10^{-7} \mathrm{~m} / \mathrm{s}$ for these units (Segadelli et al. 2017a). The olistolithes of Mt. Prinzera and Mt. Zirone are bordered and underlain by low-permeability deposits (Figs. 2 and 3) that are predominantly characterized by polygenic breccias made out of blocks of limestones or marly limestones inside a silty-clayey matrix with mineral cement (Segadelli et al. 2017a, b). It is reasonable to assume that these lower permeability units behave as aquitards, since the finegrained matrix clearly dominates over the limestone blocks (Fig. 3c). Several perennial springs are located at the contact between the ophiolitic aquifers and the aquitard unit. These springs represent the whole outflow of the aquifers following the conceptual model proposed by Segadelli et al. (2017b) for Mt. Prinzera (Fig. 4).

The climate in the Mt. Prinzera and Mt. Zirone areas is midway between Mediterranean and oceanic, with humidity levels typical of boreal mountain zones close to the sea (Costantini et al. 2013; Nistor 2016). The average annual rainfall is about $1,000 \mathrm{~mm} /$ year and the seasonal rainfall distribution is that typical of the Northern Apennines with a main peak in autumn and a secondary peak in spring (Antolini et al. 2017). The driest season is summer-early autumn followed by a dry period of secondary importance in early winter. 


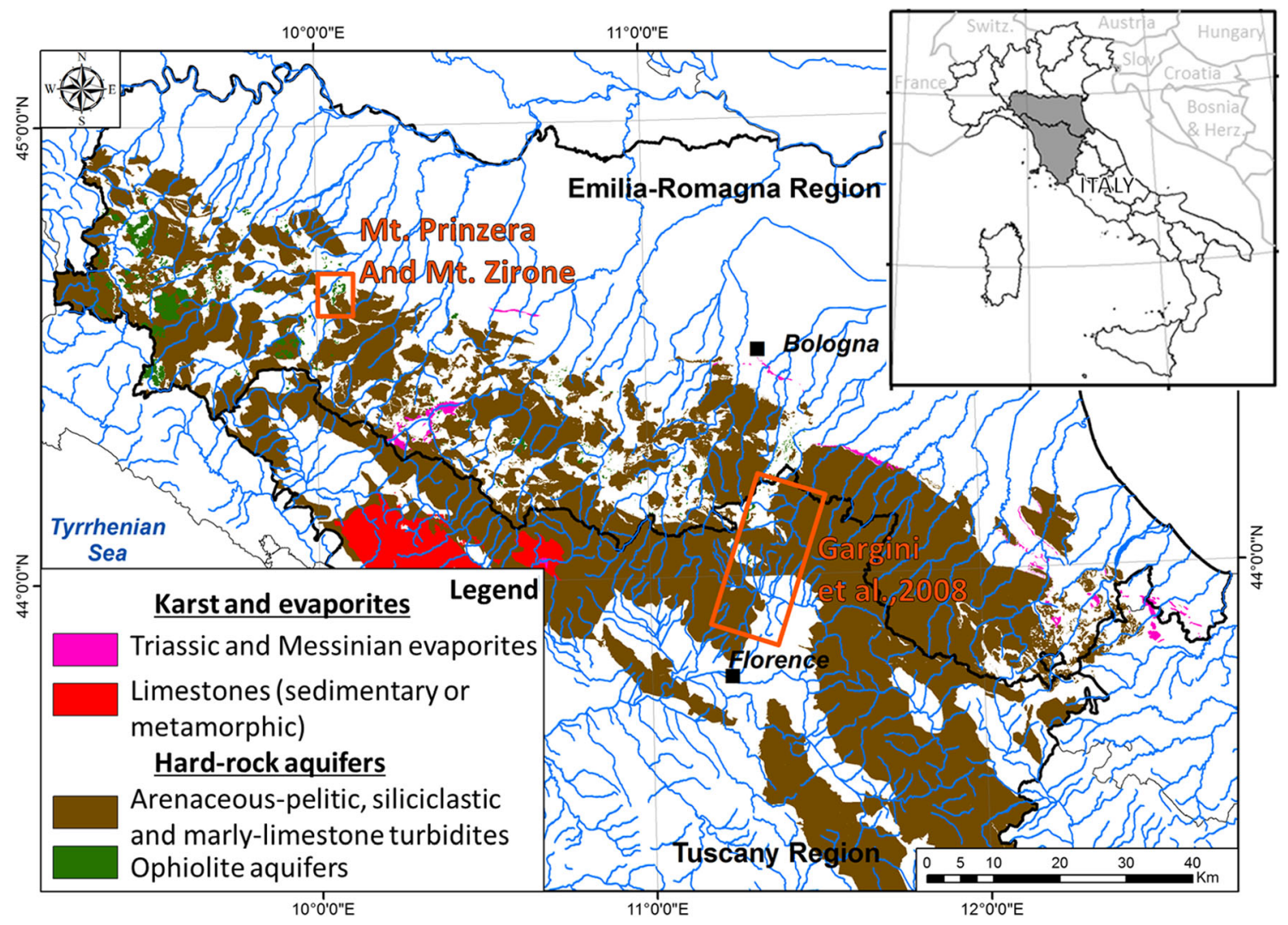

Fig. 1 Distribution of hard-rock aquifers in the Northern Apennines, Italy. The area of Mt. Prinzera and Mt. Zirone and the area previously investigated by Gargini et al. (2008) are highlighted in orange. Geological database source: Geological survey of Emilia-Romagna and Tuscany regions in GIS vector format at a scale of 1:10000

electronic supplementary material (ESM). Discharge measurements were performed using the volumetric method due to the relatively low flow rates. In the case of springs exploited for public water supply, the time to fill a $20-\mathrm{L}$ graduated bucket was measured to obtain discharge. In the case of non-exploited springs, flumes and weirs were used to convey all the water inside a smaller graduated container. Measurements were repeated at least three times at each monitoring point for the sake of accuracy. Groundwater parameters (temperature: $T$, electrical conductivity at $25^{\circ} \mathrm{C}$ : $\mathrm{EC}$, and $\mathrm{pH}$ ) were measured on-site by means of a portable device (Eutech Instrument, Thermo Fisher Scientific Inc.) concurrently with each discharge measurement.

\section{Estimation of averaged annual spring discharge}

A power-law correlation was found by Gargini et al. (2008) between the average annual discharge of a spring from field monitoring $\left(Q_{\mathrm{A}}\right)$ and its average discharge during hydrological recession in the low flow season, i.e. summer in the investigated climate $\left(Q_{\mathrm{S}}\right)$. Such correlation was derived experimentally starting from a large dataset of 11 hydrogeologic years of discharge monitoring on more than 80 springs in hard rock aquifers in turbiditic formations of the Northern Apennines and is expressed as in Eq. (1): 


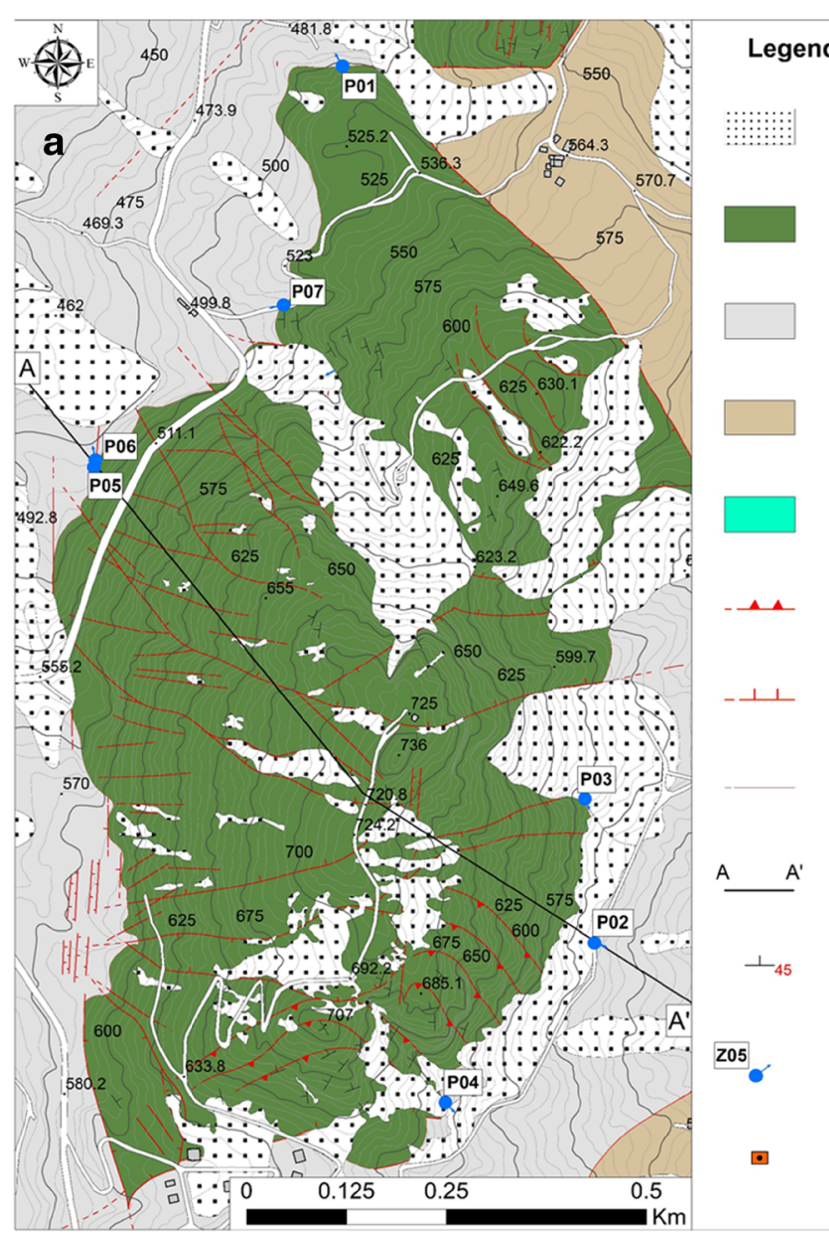

Fig. 2 Geological sketch maps of a Mt. Prinzera and b Mt. Zirone. Legend: a: Quaternary deposits; b: ophiolite hard-rock aquifers; c: polygenic breccias in clay matrix (aquitard); d: Helminthoid flysch; e:

$Q_{\mathrm{A}}=A Q_{\mathrm{S}}^{B}$

The coefficient $A$ and the exponent $B$ were obtained from the linear fitting on a log-log plot of field data pertaining to springs with similar recession coefficients $(\alpha)$. The coefficient $\alpha$ is derived from the exponential model proposed by Maillet (1905). In particular, Gargini et al. (2008) proposed six different couples of values for $A$ and $B$ corresponding to different ranges of $\alpha$ ("classes of $\alpha$ ", from here on; Table 1). The data within each of the six classes of $\alpha$ were aligned on a log-log plot of $Q_{\mathrm{A}}$ VS $Q_{\mathrm{S}}$ with a high coefficient of correlation $\left(R^{2}\right)$ between 0.99 and 0.97 . The rationale for choosing the Maillet model for the analysis of recession hydrographs is provided in the following section.

Equation (1) was applied to the springs of the Mt. Prinzera and Mt. Zirone to predict an average annual discharge $\left(Q_{\mathrm{AE}}\right.$, where the subscript $\mathrm{E}$ indicates an indirect estimate of $Q_{\mathrm{A}}$ through the equation) starting from base-flow recession monitoring $\left(Q_{\mathrm{S}}\right)$.

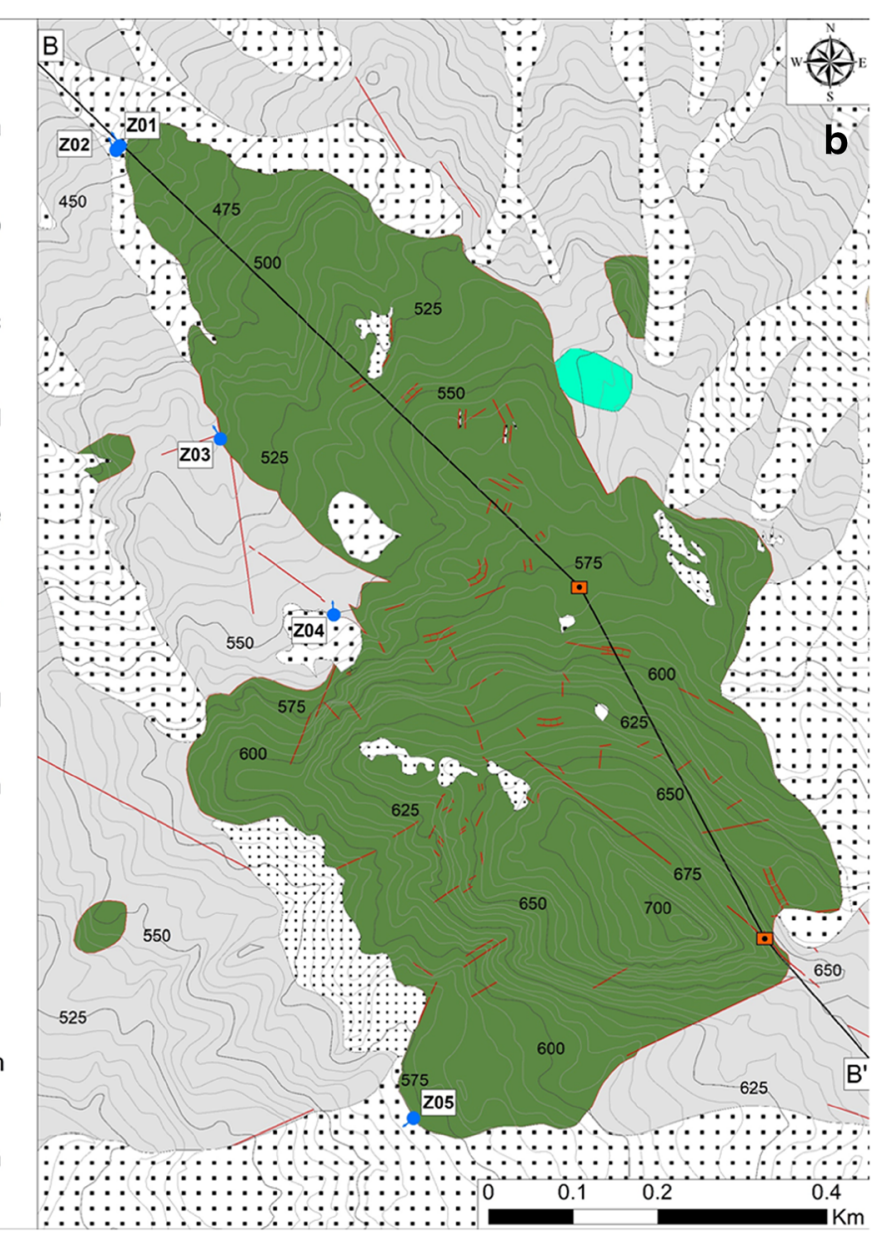

Calpionella limestones; f: thrust; g: fault (the teeth indicate the downwards moved side); h: tectonic contact; i: geological cross section; 1 : foliation attitude; m: perennial spring; $n$ : borehole

The actual averaged annual discharge $Q_{\mathrm{A}}$ was determined for each spring from field data. To account for the uneven distribution of $Q$ measurements over the hydrogeologic year, $Q_{\mathrm{A}}$ was determined for each spring by disaggregating the flow rates measurements in four seasons (fall: from start of the hydrogeologic year to December 31st; winter: from January 1st to March 31st; spring: from April 1st to June 30th; summer: from July 1st to end of the hydrogeologic year) and by averaging the four mean seasonal values. $Q_{\mathrm{S}}$ was determined for each spring by averaging only the flow measurements selected for the recession analysis (criteria for the selection are in the next section).

The estimated annual flow rates $Q_{\mathrm{AE}}$ were compared to the average annual discharge from field monitoring $Q_{\mathrm{A}}$. The goodness of the prediction was quantified separately for Mt. Prinzera and Mt. Zirone using the normalized root mean square deviation (NRMSD), expressed as in Eq. (2): 

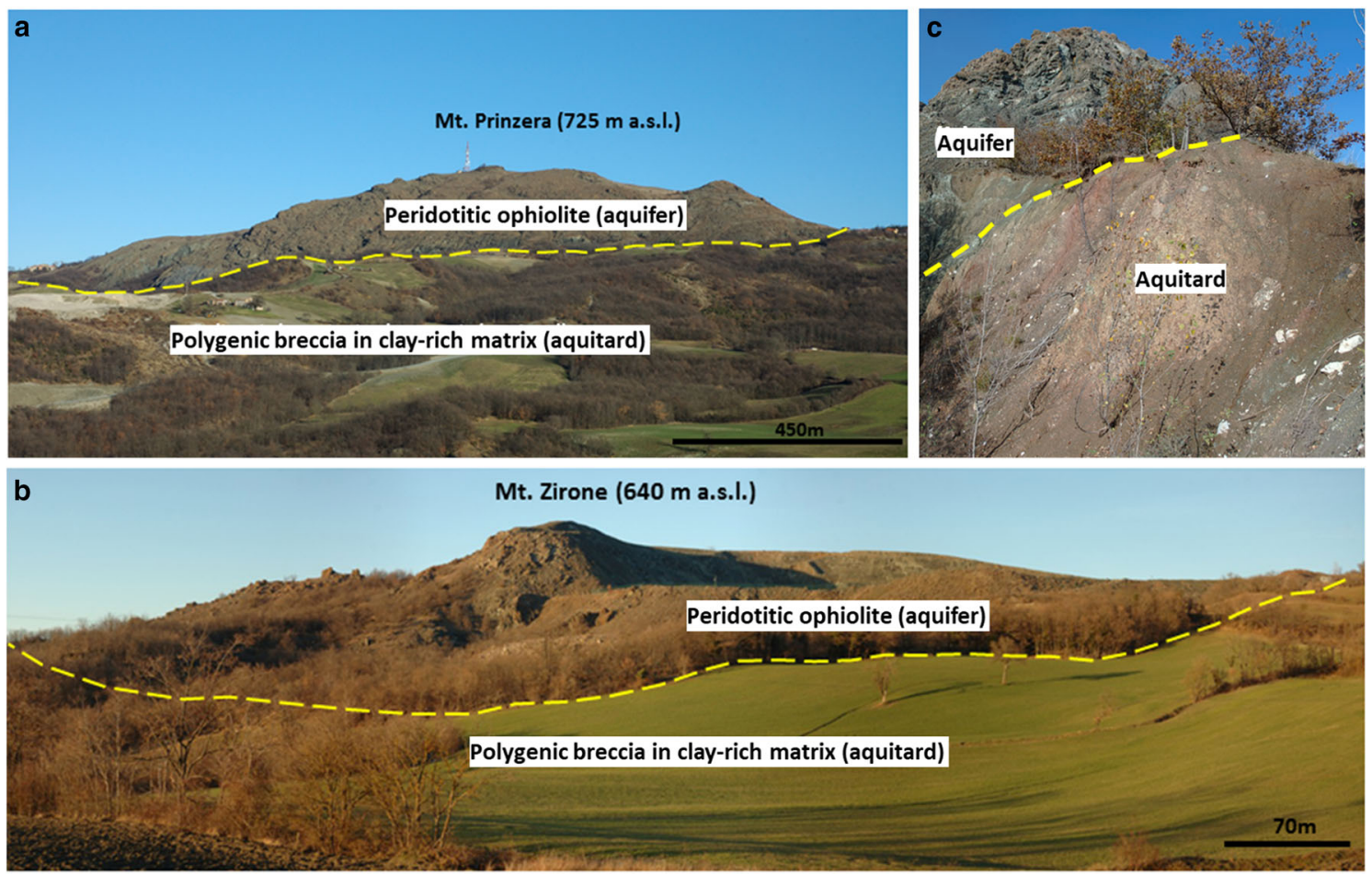

Fig. 3 a The landscape view of Mt. Prinzera western side and $\mathbf{b}$ Mt. Zirone southeastern side

The ophiolitic hard-rock aquifers rise from the surrounding gentle slopes made up of soft rocks (clay-rich breccias); $\mathbf{c}$ detail of the contact between the ophiolitic aquifer unit and the underlying aquitard

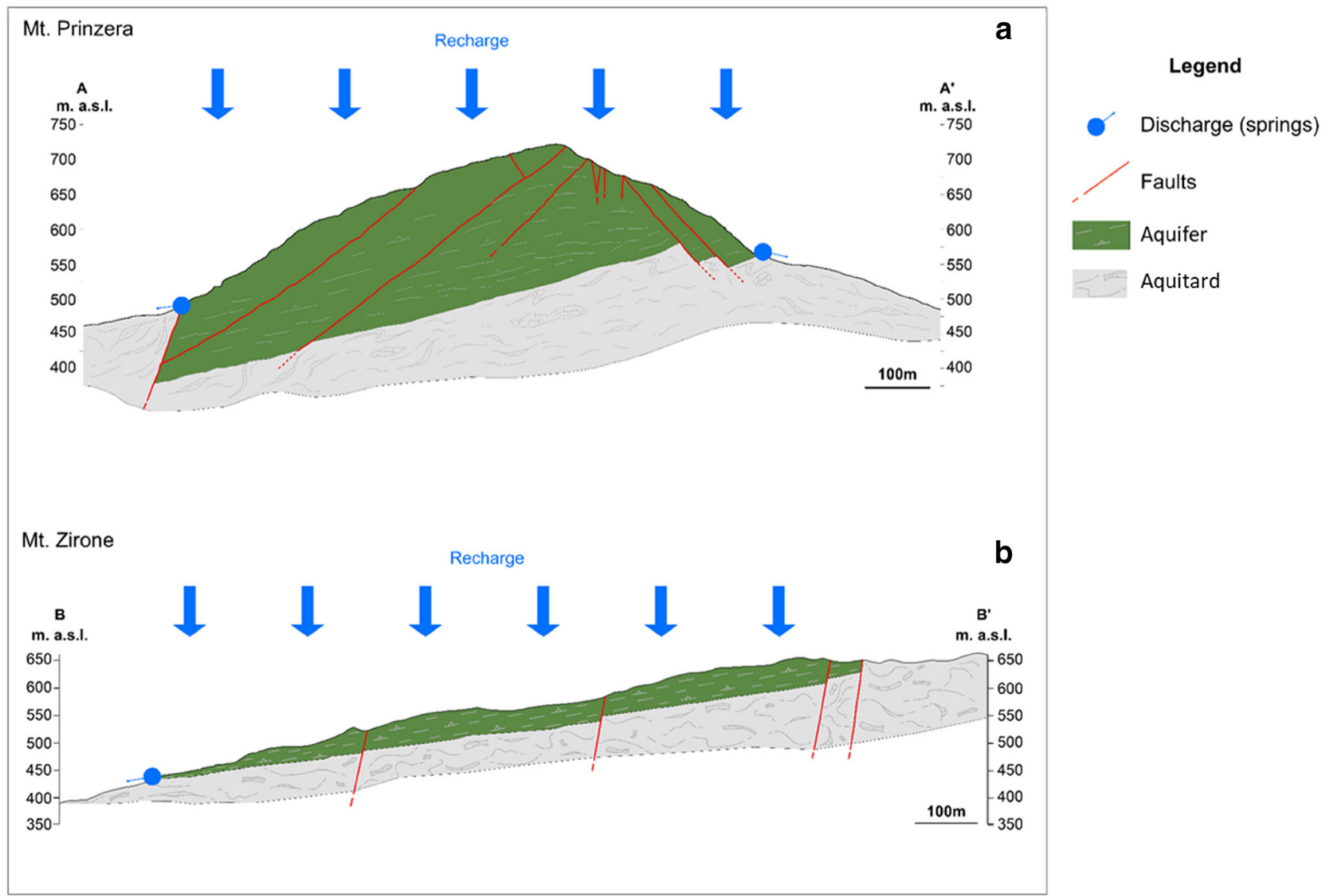

Fig. 4 Hydrogeological conceptual model of the a Mt. Prinzera and b Mt. Zirone aquifer systems. The traces of the sections are in Fig. 2 
Table 1 Classes of recession coefficient $\alpha$ proposed by Gargini et al. (2008) and the A and B values associated to each class

\begin{tabular}{llrl}
\hline Class & $\alpha\left[\right.$ day $\left.^{-1}\right]$ & $A$ & $B$ \\
\hline 1 & $>3 \times 10^{-2}$ & 13.0 & 0.99 \\
2 & $3 \times 10^{-2}$ to $2 \times 10^{-2}$ & 5.2 & 0.91 \\
3 & $2 \times 10^{-2}$ to $1 \times 10^{-2}$ & 2.6 & 0.80 \\
4 & $1 \times 10^{-2}$ to $6 \times 10^{-3}$ & 1.9 & 0.92 \\
5 & $6 \times 10^{-3}$ to $3 \times 10^{-3}$ & 1.3 & 0.93 \\
6 & $<3 \times 10^{-3}$ & 1.2 & 0.78 \\
\hline
\end{tabular}

$\mathrm{NRMSD}=\sqrt{ } 1 / n\left[\sum_{i}^{n}=1\left(Q_{\mathrm{AE} i}-Q_{\mathrm{A}}\right)^{2}\right] /\left(Q_{\mathrm{A} \max }-Q_{\mathrm{A} \min }\right)$

where $Q_{\mathrm{A} \text { max }}$ and $Q_{\mathrm{A} \text { min }}$ are the maximum and minimum averaged annual flow rates from field measurements, respectively, and $n$ is the number of monitored springs.

\section{Analysis of spring base-flow recession using the Maillet model}

The depletion hydrograph of springs and streams is the stage of the hydrograph along which the discharge decreases over time. The literature has been mostly focused on the base-flow recession, i.e. the late stage of the depletion hydrograph when streams are fed exclusively by groundwater discharge with no disturbances from recharge processes. In this stage, the recession behavior is expected to provide information on some intrinsic aquifer features (e.g. Azeez et al. 2015; Tague and Grant 2004).

One of the first studies about base-flow recession hydrographs is that of Boussinesq (1904), who proposed a nonlinear quadratic behavior of aquifer discharge during recession. That model is an exact solution of the diffusion equation (Boussinesq 1877) that describes groundwater flow through a porous medium. The solution is based on the Dupuit-Forcheimer assumptions which represent the first mathematical formulation of the ideal "Dupuit aquifer" (Dupuit 1863; Troch et al. 2013).

An approximation of the exact solution provided by Boussinesq is the linearized model proposed by Maillet (1905). Following Maillet, the relationship between the groundwater discharge of a spring or into a stream and time follow the exponential decay of Eq. (3) in the absence of outer influences such as precipitation, surface storage, groundwater abstraction or evapotranspiration:

$Q=Q_{0} \mathrm{e}^{-\alpha t}$ where $Q$ and $Q_{0}$ are the flow rates $\left(\mathrm{L}^{3} / \mathrm{T}\right)$ at time $t$ and at the beginning of the base-flow recession stage, respectively, and $\alpha$ is a time constant $\left(\mathrm{T}^{-1}\right)$ representing storage lag-time. $\alpha$ is related to the time required to halve the base-flow discharge $\left(t_{0.5}\right)$ and can be expressed as in Eq. (4):

$\alpha=-\left[(\ln 0.5) / t_{0.5}\right]$

From a mathematical viewpoint, Eq. (3) is probably the most convenient description of base-flow recession among existing models (Dewandel et al. 2003). However, rigorous hydrological analyses applied mostly to streams have demonstrated that the linearized Maillet model is inadequate to describe the whole range of groundwater discharge behaviors during base-flow recession. Semi-logarithmic recession hydrographs of actual rivers are generally concave, suggesting that $\alpha$ is not constant but instead decreases with decreasing groundwater discharge into the stream (Brutsaert and Nieber 1977; Moore 1997; Shaw and Riha 2012; Wittenberg 1994). When analyzing the literature about recession analysis, one has to take into account that the recession hydrograph of a stream can be more complex than that of a spring because stream flow is more subject to interactions with other components of the hydrological cycle such as interflow, precipitation, evapotranspiration acting within the root zone, and river bank filtration, or it may be influenced by the initial moisture conditions of the watersheds (Kirchner 2009; Shaw and Riha 2012). Differently, the base-flow recession hydrograph of a spring is expected to be a mere expression of the averaged hydrogeological features of the discharging aquifer. Because of that, the recession trends of nonkarstic springs are more likely to fit simpler models such as the linearized Maillet solution, compared to streams. For instance, Dewandel et al. (2003) showed that the recession hydrographs of springs fed by ophiolite hard rock aquifers were well reproduced either by the Maillet or the Boussinesq models, depending on aquifer features.

Notwithstanding the limitations associated with the Maillet model, it was decided to use this equation to analyze baseflow recession, for two reasons: (1) the correlation between annual and base-flow discharge proposed by Gargini et al. (2008), which is the object of validation in this study, was built on that model; (2) the model allows a simple and straightforward analysis of recession hydrographs, which is consistent with the deliberately simple approach that is proposed here for recharge estimation. It is worth noting that the recession analysis is performed with the sole scope of arranging the spring hydrographs into different classes (i.e., ranges of $\alpha$ values) representing different "types" of recession behaviors (see previous section). To this scope, a certain degree of approximation caused by linearization may be tolerable. Moreover, the subdivision in recession classes was validated using a second 
type of analysis: the so-called "recession plot" (Brutsaert and Nieber 1977) which represents another derivation of the quadratic Boussinesq model. In such analysis, the first time derivative of the discharge $(\mathrm{d} Q / \mathrm{dt})$ is plotted as a function of mean discharge $\left(Q_{\mathrm{m}}\right)$ within the dt interval, on a log-log plot. The relationship is expected to be linear with a variable range of slopes. The analysis has been successfully applied in hydrological studies of stream recession (e.g. Kirchner 2009; Shaw and Riha 2012). The slopes of the recession plots were compared with the $\alpha$ of Maillet to verify if the same arrangement in recession classes proposed by Gargini et al. (2008) was still discernible. More details on the development of recession plots are in the ESM.

For the application of the Maillet model, a time period corresponding to base-flow recession was selected within the two hydrogeologic years covered by the monitoring. In both cases, the recession season was initiated on July 1 st and lasted up until the end of the hydrogeologic year, in analogy with the recession period previously considered by Gargini et al. (2008). The choice to fix a "standard" beginning of the recession season to July 1st (regardless to the specific shape of each hydrograph) was made to test the feasibility of proposing a standard monitoring period for the estimation of recharge in climate zones similar to that of the Northern Apennines. As a first step, the recession hydrographs were handled to minimize disturbances from significant recharge events. In particular, only the progressively decreasing values of discharge were considered, making sure to keep at least three measurements for each spring. Attention was also paid to obtain a good fit of the $Q$ data along an exponential trend line with $R^{2}>0.90$. The Maillet coefficient $\alpha$ was extracted from the equation of the same exponential trend line.

\section{Results and discussion}

\section{Prediction of averaged annual flow rates}

A hydrogeologic year was identified between 25 October 2012 and 28 August 2013 at Mt. Prinzera and between 17 October 2016 and 7 September 2017 at Mt. Zirone. $Q_{\mathrm{A}}$ values in the range of 0.04 to $2.69 \mathrm{~L} / \mathrm{s}$ and of 0.11 to $1.42 \mathrm{~L} / \mathrm{s}$ were determined from field measurements at Mt. Prinzera and Mt. Zirone, respectively, whereas $Q_{\mathrm{S}}$ values ranged between 0.01 and $0.85 \mathrm{~L} / \mathrm{s}$ at Mt. Prinzera and between 0.04 and $1.30 \mathrm{~L} / \mathrm{s}$ at Mt. Zirone (Table 2). The complete data-set of $Q$ measurements is in the ESM together with the complete spring hydrographs and rainfall data from preexisting meteorological stations. Recession analysis with the Maillet model was performed on each spring hydrograph (Fig. 5) to determine $\alpha$ and the corresponding A and B parameters that drive the correlation between $Q_{\mathrm{A}}$ and $Q_{\mathrm{S}}$.
Table 2 Results from summer recession analysis at the springs of Mt. Prinzera and Mt. Zirone with measured and predicted annual flow rates $\left(\mathrm{Q}_{\mathrm{A}}\right.$ and $\mathrm{Q}_{\mathrm{AE}}$, respectively). Values in italic are totals

\begin{tabular}{lllllll}
\hline Aquifer & Spring & $\alpha\left[\right.$ day $\left.^{-1}\right]$ & Class & $Q_{\mathrm{S}}(\mathrm{L} / \mathrm{s})$ & $Q_{\mathrm{A}}(\mathrm{L} / \mathrm{s})$ & $Q_{\mathrm{AE}}(\mathrm{L} / \mathrm{s})$ \\
\hline Mt. Prinzera & P01 & $1.00 \times 10^{-2}$ & 3 & 0.848 & 2.689 & 2.279 \\
& P02 & $9.00 \times 10^{-3}$ & 4 & 0.078 & 0.224 & 0.182 \\
& P03 & $1.66 \times 10^{-2}$ & 3 & 0.033 & 0.250 & 0.170 \\
& P04 & $2.66 \times 10^{-2}$ & 2 & 0.024 & 0.172 & 0.177 \\
& P05 & $2.70 \times 10^{-2}$ & 2 & 0.077 & 0.375 & 0.505 \\
& P06 & $2.50 \times 10^{-3}$ & 6 & 0.029 & 0.038 & 0.076 \\
& P07 & $3.70 \times 10^{-3}$ & 5 & 0.012 & 0.045 & 0.021 \\
& Total: & & & 1.101 & 3.793 & 3.409 \\
Mt. Zirone & Z01 & $1.75 \times 10^{-2}$ & 3 & 0.084 & 0.141 & 0.358 \\
& Z02 & $2.65 \times 10^{-2}$ & 2 & 0.036 & 0.113 & 0.251 \\
& Z03 & $4.33 \times 10^{-2}$ & 1 & 0.114 & 0.482 & 0.151 \\
& Z04 & $2.90 \times 10^{-3}$ & 6 & 1.304 & 1.421 & 1.476 \\
& Z05 & $7.60 \times 10^{-3}$ & 4 & 0.075 & 0.150 & 0.175 \\
& Total: & & & 1.612 & 2.306 & 2.411 \\
\hline
\end{tabular}

All the seven springs fed by the Mt. Prinzera aquifer, except for P01, had at least one out of seven measurements of $Q$ excluded from the recession analysis. In particular, the $Q$ measurement of 14 July showed a deviation from the recession trend (increasing $Q$ compared to the previous measurement) in the hydrographs of P02-P07, most likely induced by the rainfall events between 11 and 14 July ( $35 \mathrm{~mm}$ in total; see ESM). For springs $\mathrm{P} 02$ and $\mathrm{P} 07$, one and two other $Q$ values were excluded from the analysis, respectively, for the same reason as already mentioned. In spring P05, a decreasing trend of four consecutive $Q$ measurements was identified starting from 21 July; the former three values were excluded because they did not follow a decreasing trend. In general, the recession hydrographs of Mt. Prinzera suggest that all the springs, with the exception of $\mathrm{P} 01$, are responsive to rainfall events occurring during the low-flow season, likely because these are connected to shallower groundwater flow systems with a lower bulk discharge compared to spring P01.

Six measurements of $Q$ were performed at the five springs of Mt. Zirone during the low-flow season. In springs Z01, Z02 and $\mathrm{Z} 04$, the $Q$ measurements of 15 and 25 July were excluded from the recession analysis since these are higher than the preceding $Q$ value on the hydrograph. These anomalies are likely related to the rainfall events between 11 and 14 July (38 $\mathrm{mm}$ in total), and that of 24 June $(10 \mathrm{~mm})$. In the case of spring Z05, the $Q$ values deviating from the decreasing trend and excluded from the analysis are that of 25 July and 8 August. The deviation of 8 August may be related to a local rainfall not detected by the available pluviometers. Spring Z03 shows a decreasing trend of three consecutive $Q$ measurements starting from 25 July; the former three values on the 

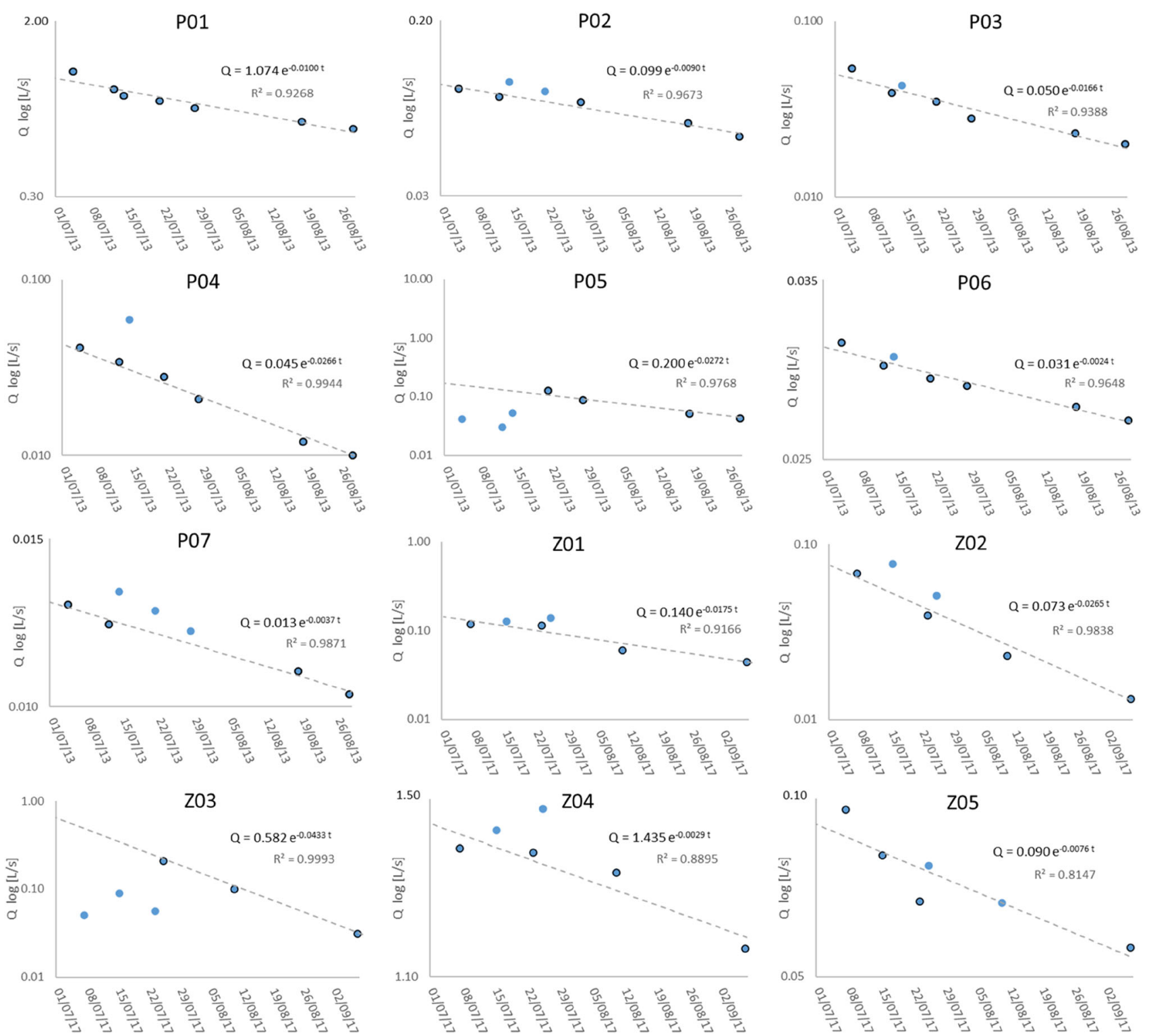

Fig. 5 Analysis of the base flow recession hydrographs of the springs of Mt. Prinzera and Mt. Zirone using the Maillet model. The blue dots bordered in black are that selected for the analysis

hydrograph were not considered since they do not follow a decreasing trend. In general, the recession hydrographs of the springs of Mt. Zirone appear less smooth compared to Mt. Prinzera. This is also reflected by the lower degree of correlation of the $Q$ measurements on the semi-log plots, with Z04 and Z05 showing a $R^{2}$ of 0.89 and 0.81 , respectively, marginally below the fixed threshold of 0.90 . This may be due to a higher reactivity to rainfall events in the Mt. Zirone aquifer compared to Mt. Prinzera, possibly driven by some intrinsic features of the aquifer, e.g. smaller aquifer basin and/or higher permeability, shallower and/or faster recharge pathways. Alternatively, the less frequent and more abundant rainfall events of the summer 2017 (Mt. Zirone monitoring) may have caused more significant deviations of $Q$ from the decreasing recession trend, compared to summer 2013 (Mt. Prinzera monitoring). In particular, 13 days of rainfall were registered out of 69 with an average of $14 \mathrm{~mm} /$ day during the summer of the hydrogeologic year 2016-2017, whereas during the summer of year 2012-2013, rainfall events occurred on 17 out of 58 days with an average of $6 \mathrm{~mm} /$ day. Nevertheless, such interannual variability was considered as an opportunity to verify the effectiveness of the proposed method in different meteorological conditions.

The Maillet coefficient $\alpha$ ranges between $2.7 \times 10^{-2}$ and $3.0 \times 10^{-3}$ days $^{-1}$ in the springs of Mt. Prinzera and between $4.3 \times 10^{-2}$ and $3.0 \times 10^{-3}$ days $^{-1}$ in the springs of Mt. Zirone. In Table 2, each spring is ranked according to the classes of $\alpha$ identified by Gargini et al. (2008). The coefficient $\alpha$ of each 
spring was compared with the slope of the recession plot $(S)$ of the same spring, showing a good linear correlation between the two on a log-log plot with $R^{2}$ of 0.87 (Fig. 6). The comparison suggests that the classes of $\alpha$ proposed by Gargini et al. (2008) are still discernible when considering the slope of a recession plot. Because of this observation, the Maillet model is considered to be a proper tool for identifying classes of recession behavior in the type of springs that are investigated within this research.

The values of $Q_{\mathrm{AE}}$ range between 0.02 and $2.28 \mathrm{~L} / \mathrm{s}$ at $\mathrm{Mt}$. Prinzera and between 0.15 and $1.48 \mathrm{~L} / \mathrm{s}$ at Mt. Zirone. A comparison between $Q_{\mathrm{A}}$ and $Q_{\mathrm{AE}}$ is shown in Fig. 7. In the case of Mt. Prinzera, the NRMSD between $Q_{\mathrm{A}}$ and $Q_{\mathrm{AE}}$ is $6.3 \%$, suggesting an overall good prediction. P06 and P07 are the springs where $Q_{\mathrm{A}}$ and $Q_{\mathrm{AE}}$ show the greatest differences compared to absolute values of averaged annual discharge. It is worth noting that these are the springs with the lowest averaged annual flow rates in the Mt. Prinzera area, in the order of $1 \times 10^{-2} \mathrm{~L} / \mathrm{s}$, and the $Q$ measurements in the field were likely affected by a higher relative error compared to the other springs. At Mt. Zirone, $Q_{\mathrm{A}}$ and $Q_{\mathrm{AE}}$ show larger differences between each other compared to the springs of Mt. Prinzera, with an NRMSD of $14.5 \%$. The noisier summer hydrographs typically observed in the Mt. Zirone springs along with the smaller number of available $Q$ measurements compared to Mt. Prinzera may have lead to higher uncertainties in the $Q_{\mathrm{AE}}$ prediction. In the case of Mt. Zirone, a continuous monitoring of flow rates (or a higher frequency of discontinuous measurements) may have helped increase the accuracy of $Q_{\mathrm{S}}$ estimates and the consequent prediction of $Q_{\mathrm{AE}}$.

The sum of $Q_{\mathrm{A}}$ in the springs of Mt. Prinzera is equal to $3.79 \mathrm{~L} / \mathrm{s}$, whereas the sum of $Q_{\mathrm{AE}}$ is $3.41 \mathrm{~L} / \mathrm{s}$, with a small difference between the two of $0.38 \mathrm{~L} / \mathrm{s}$. In the case of Mt.

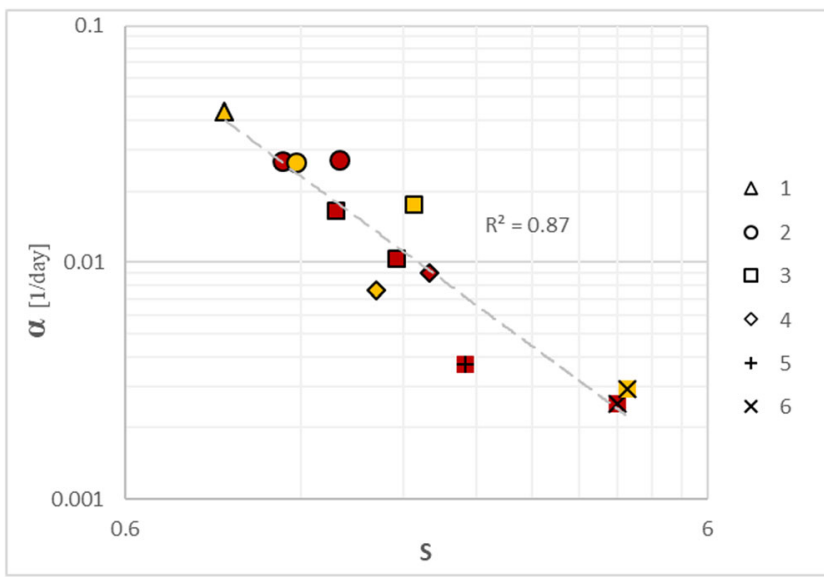

Fig. 6 Comparison between the coefficient $\alpha$ of Maillet and the slope S of the recession plot. The "recession classes" are identified with different symbol shapes. The springs of Mt. Prinzera and Mt. Zirone are depicted with red and yellow symbols, respectively

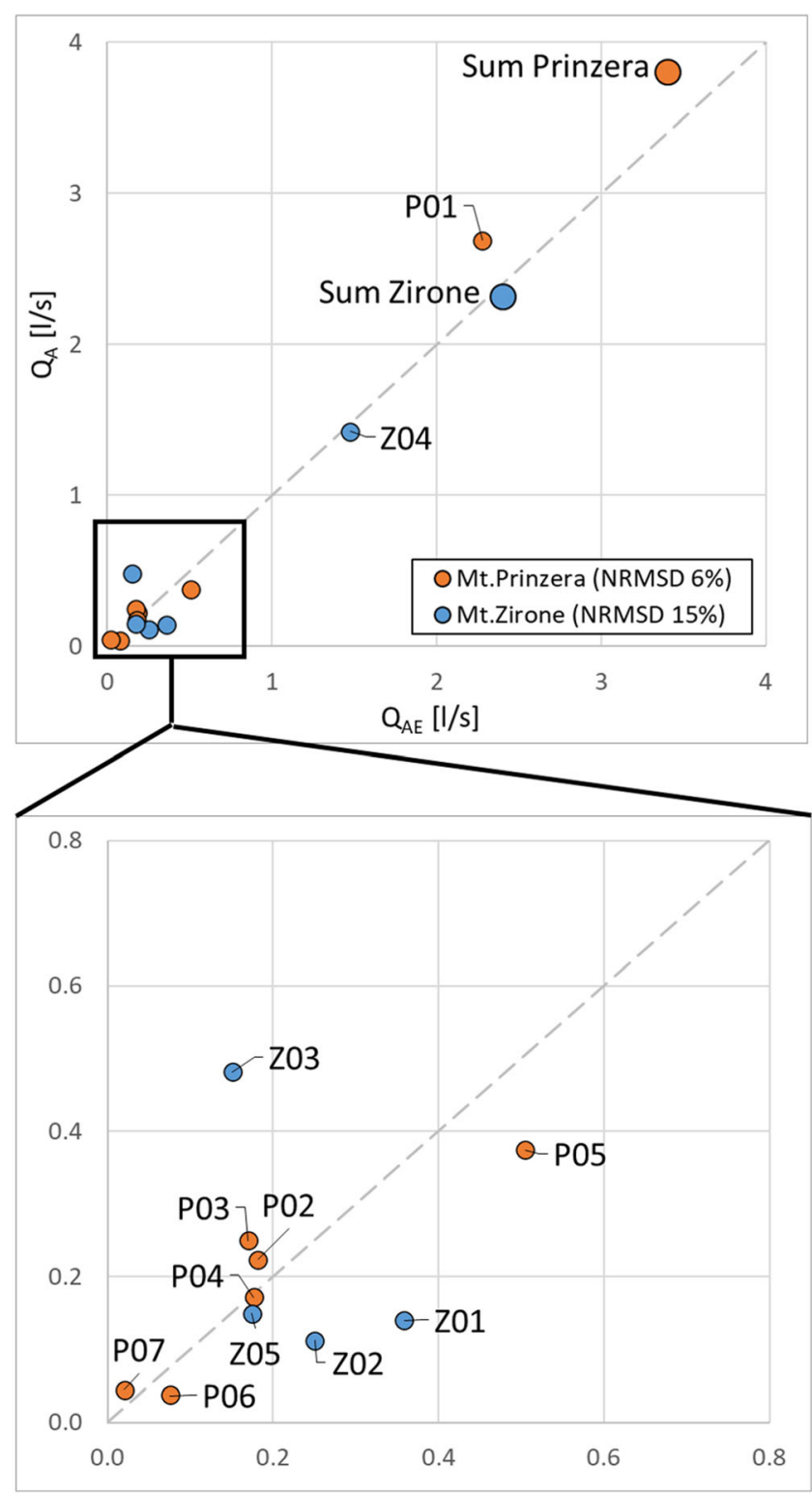

Fig. 7 Comparison between measured and predicted averaged annual flow rates $\left(Q_{\mathrm{A}}\right.$ and $Q_{\mathrm{AE}}$, respectively) at the springs of Mt. Prinzera and Mt. Zirone

Zirone, the sum of $Q_{\mathrm{A}}$ and $Q_{\mathrm{AE}}$ is respectively 2.31 and $2.41 \mathrm{~L} / \mathrm{s}$, with a difference of $0.11 \mathrm{~L} / \mathrm{s}$.

\section{Estimation of aquifer recharge}

Since the monitored springs of Mt. Prinzera and Mt. Zirone are the discharge outlets of a well-delimited aquifer system, the sum of averaged annual discharges of the two groups of springs over their catchment area corresponds to the recharge (" $R$ " from now on) of the aquifer, assuming a steady-state condition over the hydrogeologic year. Such a condition is plausible in the presence of short and relatively quick groundwater flow paths from the recharge area to the discharge points. Short and quick flow paths were inferred in the two 
aquifers based on the temperature and electrical conductivity of spring water (see data of $T$ and EC in the ESM). In detail, the average annual water temperature ranges between 10.3 and $12.5^{\circ} \mathrm{C}$ at the springs of Mt. Prinzera and between 10.4 and $12.5^{\circ} \mathrm{C}$ at the springs of Mt. Zirone, showing values very similar or slightly lower than the average annual air temperature measured at the selected meteorological stations $\left(12.0^{\circ} \mathrm{C}\right.$ in hydrogeologic year $2012-2013$ and $12.5^{\circ} \mathrm{C}$ in $2016-2017$, respectively for Mt. Prinzera and Mt. Zirone). Shallow groundwater temperature is expected to be 1 to $2{ }^{\circ} \mathrm{C}$ higher than the average annual air temperature (Anderson 2005; Benz et al. 2017). If the temperature of groundwater discharging from springs is similar to air, it likely means that the temperature signal of the recharging water is preserved down to the discharge points, which can be explained assuming short and shallow flow paths through the aquifer. The average annual EC of spring water ranges between 281 and $474 \mu \mathrm{S} / \mathrm{cm}$ at Mt. Prinzera and between 218 and $522 \mu \mathrm{S} / \mathrm{cm}$ at Mt. Zirone. Such values are in the low range of EC previously observed in literature for groundwater in ophiolitic aquifers (typically up to $2,000 \mu \mathrm{S} / \mathrm{cm}$; e.g. Abdalla et al. 2016; Dewandel et al. 2005; Güler et al. 2017), suggesting a short groundwater-rock interaction time. In particular, EC values $<850 \mu \mathrm{S} / \mathrm{cm}$ are representative of quick shallow groundwater circulation following Dewandel et al. (2005).

For the estimation of $R$, a total catchment area of 771,478 $\mathrm{m}^{2}$ was considered for Mt. Prinzera and of $534,000 \mathrm{~m}^{2}$ for Mt. Zirone (i.e. the extent of the ophiolitic outcrops), whereas the monitored hydrogeologic years lasted for 307 and 325 days, respectively. $R$ values of 130 and $117 \mathrm{~mm}$ throughout the hydrogeologic year was estimated for the Mt. Prinzera from $Q_{\mathrm{A}}$ and $Q_{\mathrm{AE}}$, respectively, whereas at Mt. Zirone $R$ values of 121 and $127 \mathrm{~mm}$ were derived from $Q_{\mathrm{A}}$ and $Q_{\mathrm{AE}}$, respectively. In both settings, estimation of $R$ from $Q_{\mathrm{A}}$ or $Q_{\mathrm{AE}}$ shows small differences $(13 \mathrm{~mm}$ at Mt. Prinzera, corresponding to the $10.6 \%$ of averaged $R$, and $6 \mathrm{~mm}$ for Mt. Zirone, equal to $4.5 \%$ of averaged $R$ ).

The values of $R$ are consistent with that estimated from an annual water budget in the two aquifers ( $R_{\mathrm{wb}}$; see ESM), when assuming a much higher infiltration potential at Mt. Zirone compared to Mt. Prinzera. Such higher infiltration is justified by a more pronounced stress-release condition (testified by rock slope deformations and fractures with larger aperture and higher persistence) and a higher percent of bedrock outcrop at Mt. Zirone compared to Mt. Prinzera, as discussed in section S6 of the ESM.

A coefficient of infiltration $(C)$ was estimated for the two aquifers of Mt. Prinzera and Mt. Zirone corresponding to the ratio between $R$ throughout the monitored hydrogeologic years (derived by $Q_{\mathrm{A}}$ or $Q_{\mathrm{AE}}$ ) and the precipitation over the aquifer catchment during the same time span $(P$, equal to 1,011 and $632 \mathrm{~mm}$, from Mt. Prinzera and Mt. Zirone, respectively; see ESM). The estimated $C$ values are 0.13 or
0.12 at Mt. Prinzera, and 0.19 or 0.20 at Mt. Zirone, starting from $Q_{\mathrm{A}}$ or $Q_{\mathrm{AE}}$, respectively. The higher $C$ values detected for Mt. Zirone compared to Mt. Prinzera are consistent with the observed higher reactivity to rainfall events for Mt. Zirone, suggesting a higher hydraulic conductivity or the occurrence of faster or preferential recharge pathways compared to Mt. Prinzera. The hypothesis is also consistent with the formerly inferred higher infiltration potential compared to Mt. Prinzera. The values of $C$ estimated for Mt. Prinzera and Mt. Zirone are similar to that experimentally derived for Northern Apennine turbiditic aquifers by various authors, ranging between 0.13 and 0.17 (Gargini et al. 2014; Piccinini et al. 2013; Vincenzi et al. 2014). Such similarity in terms of hydrodynamic properties also enhances the idea that the turbiditic units in the Northern Apennines behave as hard rock aquifers as much as peridotitic ophiolites.

\section{Major shortcomings of the proposed method for aquifer recharge estimation}

\section{Spring discharge distribution along the hydrogeologic year}

The proposed correlation between $Q_{\mathrm{A}}$ and $Q_{\mathrm{S}}$ was observed and validated on spring hydrographs typical of fractured aquifers without significant heterogeneities at the catchment scale, in a Mediterranean climate. In such settings, the spring hydrographs are most typically characterized by an overall high discharge period with several peaks during fall, winter, and early spring, followed by a generalized decrease of discharge down to base-flow recession in late-spring and summer. The methodology described in detail in section 'Analysis of spring base-flow recession using the Maillet model' is tailored over this type of discharge pattern. A different spring discharge distribution, e.g. with several maxima and baseflow recessions per hydrogeologic year, may be expected in different climates and/or in aquifers with highly heterogeneous properties at the scale of the catchment (e.g. karst aquifers). Further investigations are needed to assess whether the proposed method could be employed on spring discharge hydrographs different than that described in the preceding.

\section{Shape of the base-flow recession hydrograph}

The proposed correlation between $Q_{\mathrm{A}}$ and $Q_{\mathrm{S}}$ is driven by the Maillet model that describes an exponential decay of discharge during the base flow recession. Any deviation from the exponential decay pattern, e.g. discharge peaks caused by significant recharge events during the low flow season, may hamper the identification of a Maillet coefficient $\alpha$ representative of the spring behavior thus decreasing the reliability of the annual discharge estimate. For example, the relatively poor fit between $Q_{\mathrm{A}}$ and $Q_{\mathrm{AE}}$ observed at Mt. Zirone is likely attributable to the noisy recession hydrographs that 
challenged the identification of $\alpha$, as widely discussed in section 'Prediction of averaged annual flow rates'. In the occurrence of springs highly reactive to single recharge events, the issue of noisy hydrographs may be partly mitigated by increasing the frequency of discharge measurements so that any transitory deviation from the recession trend could be identified and conveniently managed.

\section{Assumption of steady-state flow at the scale of the hydrogeologic year}

The proposed approach for aquifer recharge estimation grounds on the assumption of a steady-state condition between aquifer recharge and spring discharge over the hydrogeologic year. Such a condition can be considered broadly valid in relatively small catchments where the main groundwater flow paths are rather quick, which is often the case of mountain hard-rock aquifers composed of fractured permeable materials of limited extent and thickness laying over an impermeable bedrock. In the case of larger aquifers where longer residence times must be considered, the correlation between $Q_{\mathrm{A}}$ and $Q_{\mathrm{S}}$ cannot be exploited for the estimation of aquifer recharge.

\section{Conclusions}

The empirical correlation proposed by Gargini et al. (2008) between the average annual discharge of a spring and its average discharge during base-flow recession was applied to two ophiolitic aquifer systems with well-defined hydrogeologic boundaries and well-identified discharge outlets (springs) at the aquifer-aquitard boundaries. The method provided a reliable estimate of average annual discharges starting from few field measurements in the low flow season, thus confirming the validity of the correlation for hard rock aquifers in a dry summer climate, regardless to bedrock lithology. The adequacy of the Maillet coefficient $\alpha$ to discriminate among recession behaviors of springs was tested through a comparison between $\alpha$ and the slope of the so-called "recession plots". The comparison proved that the different discharge behaviors inferred using $\alpha$ are still discernible when analyzing the spring recession hydrographs with a model different than that of Maillet.

Since the two investigated aquifers are "close" systems with quick groundwater circulation inferable from temperature and electrical conductivity of the spring water, the average annual discharge of springs was assumed equal to the annual aquifer recharge over the spring catchment and used to estimate coefficients of infiltration for the aquifers which turned out to be consistent with that of other fractured aquifers in the same area.

The proposed correlation would significantly reduce the time and logistic efforts for aquifer recharge estimate in mountain areas, thus supporting the application of groundwater budgets and the assessment of climate change effects on the groundwater resource.

Notwithstanding the overall good predictions obtained at the Mt. Prinzera and Mt. Zirone aquifers, the proposed method is still affected by a few shortcomings that should be carefully considered for a broader applicability, i.e. distribution of spring discharge over the hydrogeologic year, need for an "undisturbed" base-flow recession hydrograph, and the annual steady-state assumption. Further tests are needed to verify the reliability of the proposed correlation in different hard rock settings, either in similar climate zones or in regions with different seasonal variations along the hydrogeologic year (e.g. in Alpine-like settings where the low flow season is in winter).

Supplementary Information The online version contains supplementary material available at https://doi.org/10.1007/s10040-021-02317-z.

Acknowledgements We acknowledge the two anonymous reviewers and the editor for providing insightful suggestions that improved the quality of the manuscript.

Funding Open access funding provided by Alma Mater Studiorum Università di Bologna within the CRUI-CARE Agreement.

Open Access This article is licensed under a Creative Commons Attribution 4.0 International License, which permits use, sharing, adaptation, distribution and reproduction in any medium or format, as long as you give appropriate credit to the original author(s) and the source, provide a link to the Creative Commons licence, and indicate if changes were made. The images or other third party material in this article are included in the article's Creative Commons licence, unless indicated otherwise in a credit line to the material. If material is not included in the article's Creative Commons licence and your intended use is not permitted by statutory regulation or exceeds the permitted use, you will need to obtain permission directly from the copyright holder. To view a copy of this licence, visit http://creativecommons.org/licenses/by/4.0/.

\section{References}

Abbate E (1986) Apennines and Alps ophiolites and the evolution of the Western Tethys. Mem Soc Geol Ital 31:23-44

Abdalla O, Abri RA, Semhi K, Hosni TA, Amerjeed M, Clark I (2016) Groundwater recharge to ophiolite aquifer in North Oman: constrained by stable isotopes and geochemistry. Environ Earth Sci 75(15):1117

Amiotte Suchet P, Probst J-L, Ludwig W (2003) Worldwide distribution of continental rock lithology: implications for the atmospheric/soil $\mathrm{CO} 2$ uptake by continental weathering and alkalinity river transport to the oceans. Glob Biogeochem Cycles 17(2):1038. https://doi.org/ $10.1029 / 2002$ GB001891

Anderson MP (2005) Heat as a ground water tracer. Groundwater 43(6): 951-968

Antolini G, Panvan V, Tomozeiu R, Marletto V (2017) Atlante climatico dell'Emilia-Romagna 1961-2015 [Climatic atlas of the Emilia Romagna Region 1961-2015]. Environmental protection agency of the Emilia-Romagna Region (ARPAE), Bologna, Italy 
Azeez N, West LJ, Bottrell SH (2015) Numerical simulation of spring hydrograph recession curves for evaluating behavior of the East Yorkshire Chalk aquifer. In: Proceedings 14th Sinkhole Conference, Rochester, MN, 5-9 Oct 2015, National Cave and Karst Research Institute, Carlsbad, NM. pp 521-530

Benz SA, Bayer P, Blum P (2017) Global patterns of shallow groundwater temperatures. Environ Res Lett 12(3):034005

Bortolotti V, Principi G, Treves B (2001) Ophiolites, ligurides and the tectonic evolution from spreading to convergence of a Mesozoic Western Tethys segment. In: Vai GB, Martini IP (eds) Anatomy of an Orogen: the Apennines and adjacent Mediterranean basins. Springer, Dordrecht, The Netherlands, pp 151-164

Boussinesq J (1877) Essai Sur la théorie des eaux courantes du mouvement nonpermanent des eaux souterraines [Essay on the theory of flowing waters and the transient movement of groundwater]. Acad Sci Inst Fr (23):252-260

Boussinesq J (1904) Recherches théoriques sur l'écoulement des nappes d'eau infiltrées dans le sol et sur le débit des sources [Theoretical research on the flow of water infiltrated into the ground and on the flow of sources]. J Math Pures Appl 10:5-78

Brutsaert W, Nieber JL (1977) Regionalized drought flow hydrographs from a mature glaciated plateau. Water Resour Res 13(3):637-643

Costantini EAC, Fantappié M, L'Abate G (2013) Climate and pedoclimate of Italy. In: Costantini EAC, Dazzi C (eds) The soils of Italy. Springer, Dordrecht, pp 19-37

Cuthbert MO (2010) An improved time series approach for estimating groundwater recharge from groundwater level fluctuations. Water Resour Res 46(9):W09515. https://doi.org/10.1029/ 2009WR008572

de Vries JJ, Simmers I (2002) Groundwater recharge: an overview of processes and challenges. Hydrogeol J 10(1):5-17

Dewandel B, Lachassagne P, Bakalowicz M, Weng P, Al-Malki A (2003) Evaluation of aquifer thickness by analysing recession hydrographs: application to the Oman ophiolite hard-rock aquifer. J Hydrol 274(1):248-269

Dewandel B, Lachassagne P, Boudier F, Al-Hattali S, Ladouche B, Pinault J-L, Al-Suleimani Z (2005) A conceptual hydrogeological model of ophiolite hard-rock aquifers in Oman based on a multiscale and a multidisciplinary approach. Hydrogeol J 13(5):708-726

Dewandel B, Lachassagne P, Wyns R, Maréchal JC, Krishnamurthy NS (2006) A generalized 3-D geological and hydrogeological conceptual model of granite aquifers controlled by single or multiphase weathering. J Hydrol 330(1):260-284

Dewandel B, Lachassagne P, Zaidi FK, Chandra S (2011) A conceptual hydrodynamic model of a geological discontinuity in hard rock aquifers: example of a quartz reef in granitic terrain in South India. J Hydrol 405(3):474-487

Di Dio G, Martini A, Lasagna S, Zanzucchi G (2005) Note illustrative della Carta Geologica d'Italia alla scala 1:50.000, Foglio ${ }^{\circ} 199$ Parma Sud-Ovest [Explanatory notes of the Geologic Map of Italy at the scale 1:50,000, Sheet no. 199 Parma Sud-Ovest]. Servizio Geologico della Regione Emilia-Romagna, Servizio Geologico Nazionale, ISPRA, Rome

Dupuit JÉJ (1863) Études théoriques et pratiques sur le mouvement des eaux dans les canaux découverts et à travers les terrains perméables: avec des considérations relatives au régime des grandes eaux, au débouché à leur donner, et à la marche des alluvions dans les rivières à fond mobile [Theoretical and practical studies on the movement of water in open canals and through permeable soils: with considerations on the regime of large waters, their potential outlet, and the progress of floods in rivers with moving bottoms]. Dunod, Paris

Gargini A, Piccinini L, Martelli L, Rosselli S, Bencini A, Messina A, Canuti P (2006) Hydrogeology of turbidites: a conceptual model derived by the geological survey of Tuscan-Emilian Apennines and the environmental monitoring for the high speed railway tunnel connection between Florence and Bologna. Boll Soc Geol Ital 125(3):293-327

Gargini A, Vincenzi V, Piccinini L, Zuppi G, Canuti P (2008) Groundwater flow systems in turbidites of the northern Apennines (Italy): natural discharge and high speed railway tunnel drainage. Hydrogeol J 16(8):1577-1599

Gargini A, De Nardo MT, Piccinini L, Segadelli S, Vincenzi V (2014) Spring discharge and groundwater flow systems in sedimentary and ophiolitic hard rock aquifers: experiences from northern Apennines (Italy). In: Sharp JM (ed) Fractured rock hydrogeology. CRC, Boca Raton, FL, pp 129-143

Güler C, Thyne GD, Tağa H, Yıldırım U (2017) Processes governing alkaline groundwater chemistry within a fractured rock (Ophiolitic Mélange) aquifer underlying a seasonally inhabited headwater area in the Aladağlar range (Adana, Turkey). Geofluids 2017, Article ID $3153924,21 \mathrm{pp}$

Gustafson G, Krásný J (1994) Crystalline rock aquifers: their occurrence, use and importance. Appl Hydrogeol 2(2):64-75

Healy RW (2010) Estimating groundwater recharge. Cambridge University Press, Cambridge, UK

Hilberg S (2016) Review: natural tracers in fractured hard-rock aquifers in the Austrian part of the eastern Alps: previous approaches and future perspectives for hydrogeology in mountain regions. Hydrogeol J 24(5):1091-1105

Huet M, Chesnaux R, Boucher M-A, Poirier C (2016) Comparing various approaches for assessing groundwater recharge at a regional scale in the Canadian Shield. Hydrol Sci J 61(12):2267-2283

Kirchner JW (2009) Catchments as simple dynamical systems: catchment characterization, rainfall-runoff modeling, and doing hydrology backward. Water Resour Res 45(2). https://doi.org/10.1029/ 2008WR006912

Lachassagne P (2008) Overview of the hydrogeology of hard rock aquifers: applications for their survey, management, Modelling and protection. In: Ahmed S, Jayakumar R, Salih A (eds) Groundwater dynamics in hard rock aquifers: sustainable management and optimal monitoring network design. Springer, Dordrecht, The Netherlands, pp 40-63

Lachassagne P, Wyns R, Dewandel B (2011) The fracture permeability of hard rock aquifers is due neither to tectonics, nor to unloading, but to weathering processes. Terra Nova 23(3):145-161

Maillet ET (1905) Essais d'hydraulique souterraine \& fluviale [Essay on underground and fluvial hydraulics]. Hermann, Paris

Marroni M, Meneghini F, Pandolfi L (2010) Anatomy of the LigurePiemontese subduction system: evidence from late Cretaceousmiddle Eocene convergent margin deposits in the northern Apennines, Italy. Int Geol Rev 52(10-12):1160-1192

Moore RD (1997) Storage-outflow modelling of streamflow recessions, with application to a shallow-soil forested catchment. J Hydrol 198(1):260-270

Neuman SP (2005) Trends, prospects and challenges in quantifying flow and transport through fractured rocks. Hydrogeol J 13(1):124-147

Nistor MM (2016) Spatial distribution of climate indices in the EmiliaRomagna region. Meteorol Appl 23(2):304-313

Piccinini L, Vincenzi V, Pontin A, Andreella G, D’Agostini S (2013) Groundwater drainage into a tunnel in fractured rock mass (Flysch): numerical modeling to predict maximum rate of water drainage. Geoingegneria Ambientale Mineraria 140(3):5-20

Rohde MM, Edmunds WM, Freyberg D, Sharma OP, Sharma A (2015a) Estimating aquifer recharge in fractured hard rock: analysis of the methodological challenges and application to obtain a water balance (Jaisamand Lake Basin, India). Hydrogeol J 23(7):1573-1586

Rohde MM, Edmunds WM, Sharma S (2015b) An accessible hydrogeological tool to monitor critical groundwater resources in hard-rock aquifers. Front Environ Sci 3(67). https://doi.org/10. 3389/fenvs.2015.00067 
Scanlon BR, Healy RW, Cook PG (2002) Choosing appropriate techniques for quantifying groundwater recharge. Hydrogeol J 10(1): $18-39$

Segadelli S, Vescovi P, Chelli A, Petrella E, De Nardo MT, Gargini A, Celico F (2017a) Hydrogeological mapping of heterogeneous and multi-layered ophiolitic aquifers (mountain Prinzera, northern Apennines, Italy). J Maps 13(2):737-746

Segadelli S, Vescovi P, Ogata K, Chelli A, Zanini A, Boschetti T, Petrella E, Toscani L, Gargini A, Celico F (2017b) A conceptual hydrogeological model of ophiolitic aquifers (serpentinised peridotite): the test example of Mt. Prinzera (northern Italy). Hydrol Process 31(5): 1058-1073

Shaw SB, Riha SJ (2012) Examining individual recession events instead of a data cloud: using a modified interpretation of $\mathrm{dQ} / \mathrm{dt}-\mathrm{Q}$ streamflow recession in glaciated watersheds to better inform models of low flow. J Hydrol 434:46-54

Springer A, Stevens L (2009) Spheres of discharge of springs. Hydrogeol J 17(1):83-93

Tague C, Grant GE (2004) A geological framework for interpreting the low-flow regimes of Cascade streams, Willamette River basin, Oregon. Water Resour Res 40(4). https://doi.org/10.1029/ 2003WR002629

Thivya C, Chidambaram S, Rao MS, Gopalakrishnan M, Thilagavathi R, Prasanna MV, Nepolian M (2016) Identification of recharge processes in groundwater in hard rock aquifers of Madurai District using stable isotopes. Environ Process 3(2):463-477
Troch PA, Berne A, Bogaart P, Harman C, Hilberts AGJ, Lyon SW, Paniconi C, Pauwels VRN, Rupp DE, Selker JS, Teuling AJ, Uijlenhoet R, Verhoest NEC (2013) The importance of hydraulic groundwater theory in catchment hydrology: the legacy of Wilfried Brutsaert and Jean-Yves Parlange. Water Resour Res 49(9):5099-5116

Venturelli G, Contini S, Bonazzi A, Mangia A (1997) Weathering of ultramafic rocks and element mobility at Mt. Prinzera, northern Apennines, Italy. Mineral Mag 61(409):765-778

Vincenzi V, Gargini A, Goldscheider N (2009) Using tracer tests and hydrological observations to evaluate effects of tunnel drainage on groundwater and surface waters in the northern Apennines (Italy). Hydrogeol J 17(1):135-150

Vincenzi V, Gargini A, Goldscheider N, Piccinini L (2014) Differential hydrogeological effects of draining tunnels through the northern Apennines, Italy. Rock Mech Rock Eng 47(3):947-965

Viviroli D, Dürr HH, Messerli B, Meybeck M, Weingartner R (2007) Mountains of the world, water towers for humanity: typology, mapping, and global significance. Water Resour Res 43(7):W07447. https://doi.org/10.1029/2006WR005653

Wittenberg H (1994) Nonlinear analysis of flow recession curves. IAHS Publ. no. 221, IAHS, Wallingford, UK, pp 61-68

Publisher's note Springer Nature remains neutral with regard to jurisdictional claims in published maps and institutional affiliations. 